\title{
Performance Analysis of Wind Turbine as a DISTRIBUTED GENERATION UNIT IN DisTRIBUTION SYSTEM
}

\author{
Ramadoni Syahputra ${ }^{1,2}$, Imam Robandi ${ }^{1}$, and Mochamad Ashari ${ }^{1}$ \\ ${ }^{1}$ Department of Electrical Engineering, Faculty of Industrial Technology \\ Institut Teknologi Sepuluh Nopember, Surabaya, Indonesia \\ ${ }^{2}$ Department of Electrical Engineering, Faculty of Engineering, \\ Universitas Muhammadiyah Yogyakarta, Yogyakarta, Indonesia
}

\begin{abstract}
In this paper, the performance analysis of wind turbine as a distributed generation unit is presented. In this study a model of wind power is driven by an induction machine. Wind power that is distributed generation is capable of supplying power to ac power distribution network. Wind power generation system is modeled and simulated using Matlab Simulink software such that it can be suitable for modeling some kind of induction generator configurations. To analyze more deeply the performance of the wind turbine system, both normal and fault conditions scenarios have been applied. Simulation results prove the excellent performance of the wind power unit under normal and fault conditions in the power distribution system.
\end{abstract}

\section{KEYWORDS}

Distributed generation, wind turbine, asynchronous machine, performance analysis, distribution system.

\section{INTRODUCTION}

There are three major challenges in the world at present, i.e. conservation of energy resources, protection of environmental and development of sustainable [1]. One of the important issues is how to satisfy the needs of energy for people without causing depletion of the natural energy resources rapidly and damage the environmental. In power electrical energy field, the use of Distributed Generation (DG) has the new issue in the last decade. DG is related to the use of small generating units, usually less than $10 \mathrm{MW}$, that are connected to transmission or distribution systems. The emerging new technologies such as wind energy, fuel cells, solar photovoltaics, and microhydro power sources make DG more and more affordable and popular [2]. The government of Indonesia has targeted that DG from renewable energy resources for up to $25 \%$ of all electrical power generation capacity going online to the distribution network by the year 2025 [3]. The target has been emerged because the fuel and coal energy sources are limited and have pollution to the environment.

One of the most popular technologies in DG resources is wind energy. Wind energy is the most promising and fastest growing renewable energy source among them due to economically viable [4-7]. Many applications of wind generation can be found in a wide power range from a few kilowatts to several megawatts in small scale off-grid standalone systems or large scale gridconnected wind farms. Enercon has constructed a wind turbine of $4.5 \mathrm{MW}$ with rotor diameter of $112.8 \mathrm{~m}$. Due to lack of control on active and reactive power, this type of DG causes problems in 
the electrical power connected system. So the system requires accurate modeling, control and selection of appropriate wind energy conversion system.

Over the past three decades, the high penetration of wind power in power systems has been closely associated with the progress of wind turbine technology and control methods turbine. Applications are usually induction generator used in wind farms receiving increasing attention for wind power systems for such situations. Since the main advantage of the generator is that, if the rotor current set applying field orientation control is done by using a commercial double-sided PWM inverter, the stator side controls separated the results of active power and reactive power and power converters are processed by only a small fraction of the total system power. Thus, induction generator with vector control very attractive with very high performance in the application of variable speed drives and power generation applications [8-11]. With the increasing penetration of wind power is integrated on the interconnection of large-scale power system, it would require a more in-depth research on improving the performance and technical control of wind power plants. In this paper, the development of a dynamic model of the induction machine can be simulated in the model reference frame with the vector control was conducted to test control strategies. Through the model developed in this paper it is expected to be used for the simulation of all types of induction generator configuration. Induction machine is modeled in vectorized form in the synchronous reference frame. Speed controlled induction machine using turbine pitch control to maximize the power generated at the wind speed rating that has been determined. A complete simulation model is developed for the induction machine in wind power generation systems in operation speed changing devices using MATLAB Simulink software.

\section{FUNDAMENTAL THEORY}

\subsection{Distributed Generation}

In the future, Distributed Generation (DG) is expected to provide the most economical solution for load growth. The impact due to load growth such as low voltage or overload is expected to be resolved by applying the DG in many locations. There are many locations in a series of problems, where the DG may be located to provide the necessary control to overcome the problems of voltage drop. In theory, the DG is able to provide the lowest cost solution to the problem and the circuit will be installed to provide the required voltage control. DG further placement in the circuit can lead to improvements in both losses and reliability of the electrical power system.

\subsection{Wind Energy System}

Have made many effort to build large-scale wind-powered systems to generate electrical energy. Historically, power generation using wind power in the world created by Charles Bush in Cleveland, Ohio, USA in 1887. In creation of wind power, he uses a DC generator for electricity production and is designed to charge the battery. While the use of an induction generator as wind power for the first time was in 1951.

In the principle of operation, wind turbines convert the kinetic energy contained in wind into mechanical energy in the form of a round by way of producing torque. The amount of kinetic energy generated depends on the air density and wind speed. This is due to the energy contained in wind is in the form of kinetic energy. The power generated from wind turbines is given by equation (1) [12]:

$$
P=\frac{1}{2} C_{P} \rho A V^{3}
$$


where $C_{p}$ is coefficient of power, $\rho$ is the air density in $\mathrm{kg} / \mathrm{m}^{3}$, A is the area of the turbine blades in $\mathrm{m}^{2}$ and $\mathrm{V}$ is the velocity of wind in $\mathrm{m} / \mathrm{s}$. Power coefficient $\mathrm{C}_{\mathrm{p}}$ contributes only a small fraction of the kinetic energy is converted into mechanical energy by wind turbines. The power coefficient is a function of the tip speed ratio $\lambda$ and blade pitch depending on the angle. Tip speed ratio can be defined as the ratio of the linear speed of the turbine blade and wind speed which can be expressed by the following equation:

$$
\lambda=\frac{R \omega}{V}
$$

Substituting (2) in (1), then:

$$
P=\frac{1}{2} C_{P}(\lambda) \rho A\left(\frac{R}{\lambda}\right)^{3}(\omega)^{3}
$$

The output torque of the wind turbine calculated by the equation (4):

$$
P=\frac{\vdots}{2} \rho A C_{P}\left(\frac{V}{A}\right)
$$

where $\mathrm{R}$ is the radius of the wind turbine rotor $(\mathrm{m})$. There is a value of tip speed ratio in which the coefficients vary maksimum. Turbin winds made to capture the maximum energy, thus providing optimum tip speed ratio. This can be done by changing the speed of the turbine is proportional to the change in wind speed. Figure 1 shows how variable speed wind turbine that will allow wind turbines to capture more energy from the wind [13]. As can be seen, the maximum power meets cubic relationship. For the generation of variable speed induction machine is considered attractive because it has the characteristics of a flexible rotor speed, while the characteristic of synchronous generator speed is constant.

In this study, rotor induction machine running at sub-synchronous speed to wind speed lower than $10 \mathrm{~m} / \mathrm{s}$. Furthermore the machine rotors running at super-synchronous speed for higher wind speeds. Mechanical power wind turbine as a function of the speed of the wind turbine at speeds ranging from $4 \mathrm{~m} / \mathrm{s}$ to $10 \mathrm{~m} / \mathrm{s}$ is shown in Fig. 1 .

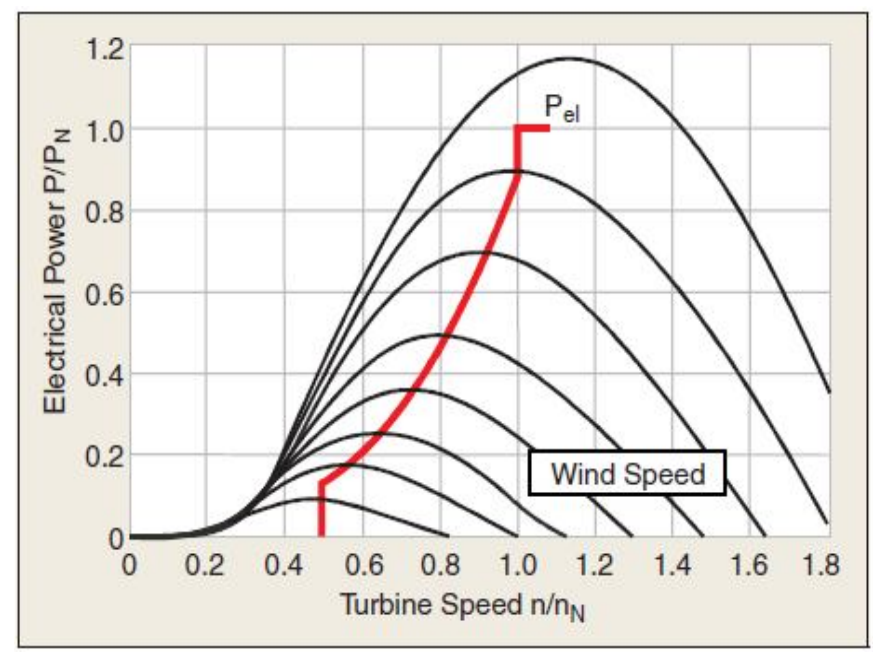

Fig.1. A common characteristic of wind turbines [13] 


\subsection{Induction Machine in Wind Energy}

Induction machine is widely used in power system as an electric motor, but not the induction machine is widely used as electrical generators [14]. Although it has simplicity in construction, induction motors do not like as much as synchronous generators. This is mainly due to the output and absorption of active and reactive power that the correlation is not good. However, induction generators provide useful damping torque is great as main propulsion, making it suitable for applications in the fixed-speed wind turbines. Wind turbines that have a fixed rate using a squirrel cage induction generator-type combined with large-scale power system through a transformer. To overcome the differences in speed of operation of the wind turbine rotor and generator, the gearbox used to match this speed. Slip of generators therefore varies slightly with the amount of power generated and therefore not entirely constant.

The general concept of induction machines in wind power generation system is shown in Fig.2. [14]. Induction machine system to date is considered the most suitable for use on wind power. Turbine speed can be controlled by the load, not by adjusting the turbine. In general, the management company has several electrical load management capabilities, but most of the burden they can not be controlled by the utility. Therefore, the utility adjusts the input prime mover to follow load variations. That is, in this case the supply keep pace with demand. In the case of wind power, the input power wind turbine wind power only and not subject to control. Speed wind turbine still needs to be controlled for optimum performance, and this can be achieved by the electrical load with the appropriate characteristics. in this case a microcomputer not so important for the mode of operation, but does not allow more flexibility in the choice of the load. We can have a system where demand follows the supply, the situation is inherently desirable.

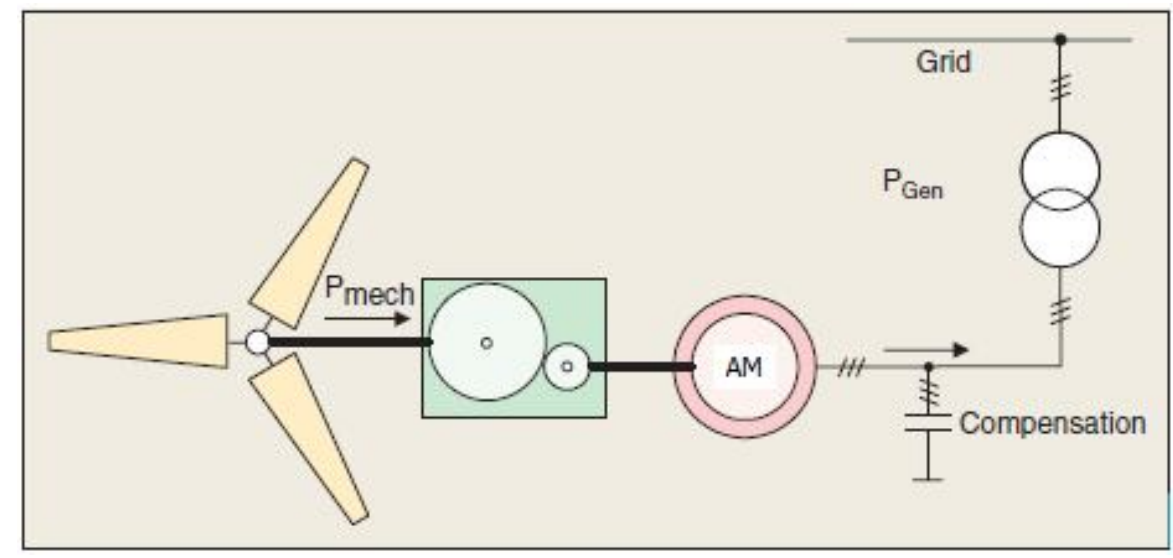

Fig.2. Typical of induction machine in wind energy conversion system [14].

Most of the leading wind turbine manufacturer in the world uses a system of induction machine [15]. The use of induction machines is due to the fact that the power electronic converter must handle only a small fraction $(20 \%-30 \%)$ of the total power, ie, the power slipping. This means that if the speed is within the range of $\pm 30 \%$ around the synchronous speed, the converter is rated for $30 \%$ of the turbine power generated, reducing the losses in the power electronic converter. This is in comparison with which the system must handle the total power converter. Apart from that the other consideration is the cost of the converter becomes lower. Induction machine has been used in wind power for a long time. At the beginning used in the past, from AC to AC converter connected to the rotor which consists of the rectifier and inverter that utilizes thyristor bridge. The technology used today is that the AC-AC converter is equipped with bi-directional IGBT, which connects the rotor of the variable speed induction generators to the power grid. 


\section{SYSTEM MODELING}

In this research, physical model of the wind power generation system with induction machine connected to grid of distribution system is implemented in Matlab Simulink software. The physical system models constituting elements of the system separately and also considers interrelationship among different elements within the system, where type and structure of the model is normally dictated by the particular requirements of the analysis, e.g. steady-state, fault studies, etc. Fig.3. shows wind turbines connected to a distribution system, while Fig.4. shows the wind turbines model, both in Simulink-Matlab software.

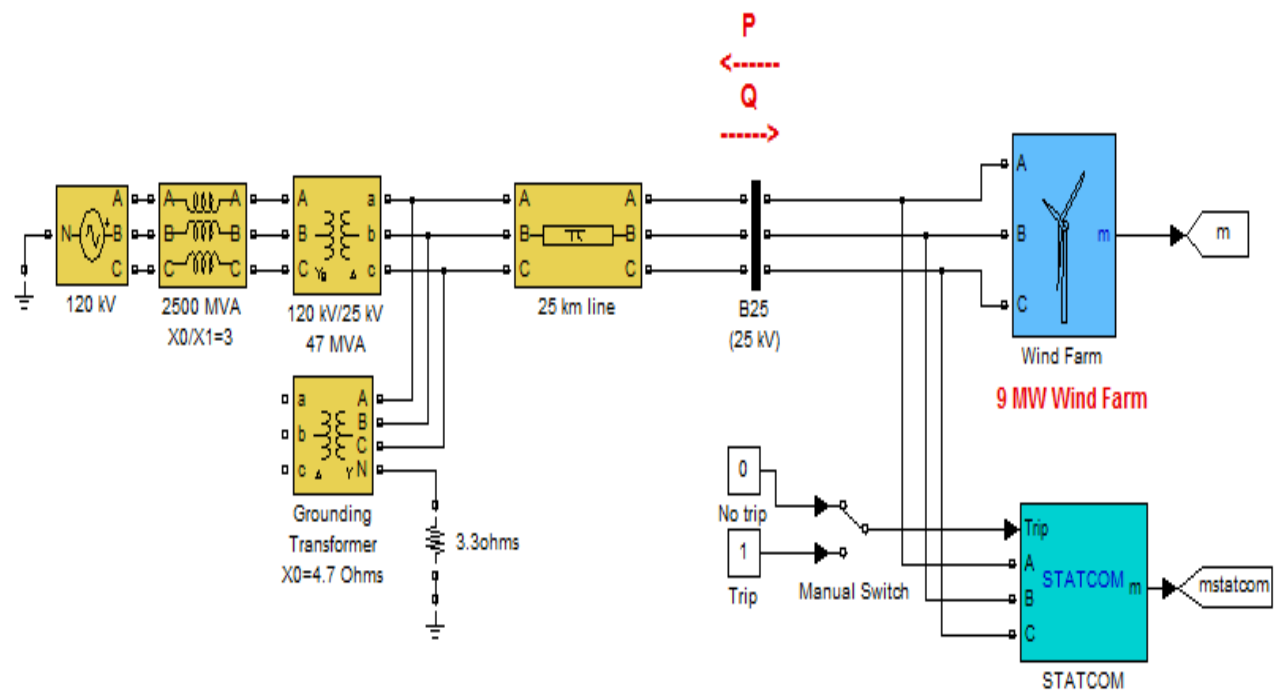

Fig.3. Wind turbines connected to a distribution system.

In Fig. 5. shown a model wind turbine and induction machines. Caused by the production of a more realistic importance of induction machine behavior, it is intended to adopt the physical model rather than a functional model to assess the performance of the induction machine. Induction machine has to be excellent in wind power generation systems. A wind power system consisting of six 1.5 MW wind turbines connected to the electric distribution system exports 25 $\mathrm{kV}$ to $120 \mathrm{kV}$ grid through a $25 \mathrm{~km} 25 \mathrm{kV}$ feeders. wind power plant with a capacity of $9 \mathrm{MW}$ modeled by three pairs of 1.5-MW wind turbines. Induction machines used in wind turbine models using machine induction squirrel-cage type. Stator coils are connected directly to the 60 $\mathrm{Hz}$ grid and the rotor is driven by a wind turbine having a variable-pitch. Pitch angle is controlled to limit the power output of the generator at the nominal value for the wind speed exceeds the nominal $(9 \mathrm{~m} / \mathrm{s})$. In order to generate optimal induction engine, the engine speed should induski slightly above synchronous speed. In this simulation speed varies between 1 pu no load and 1,005 p.u. at full load. Each wind turbine has a monitoring system voltage protection, current and engine speed. 
International Journal of Computer Science \& Information Technology (IJCSIT) Vol 6, No 3, June 2014

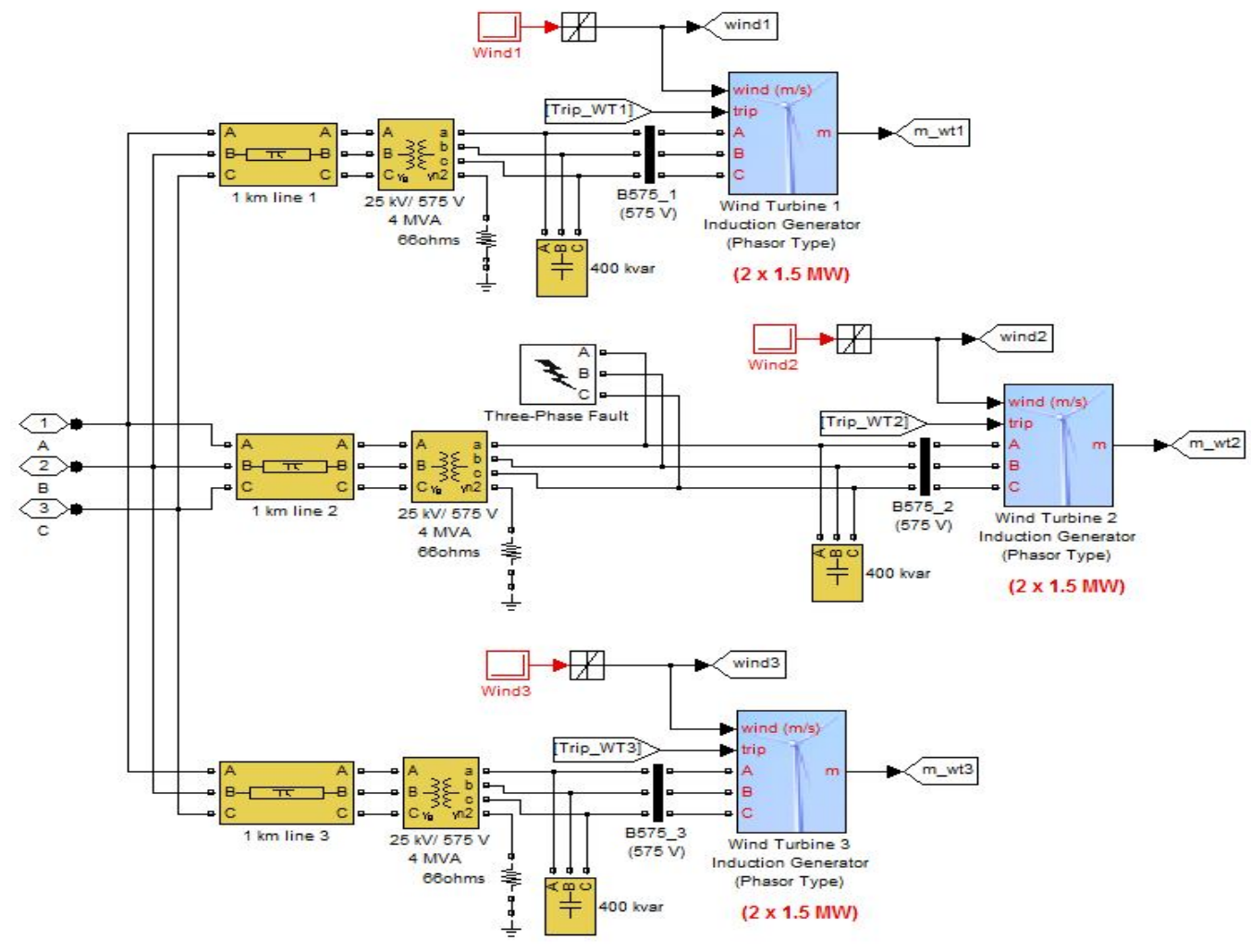

Fig.4. Wind turbines model.

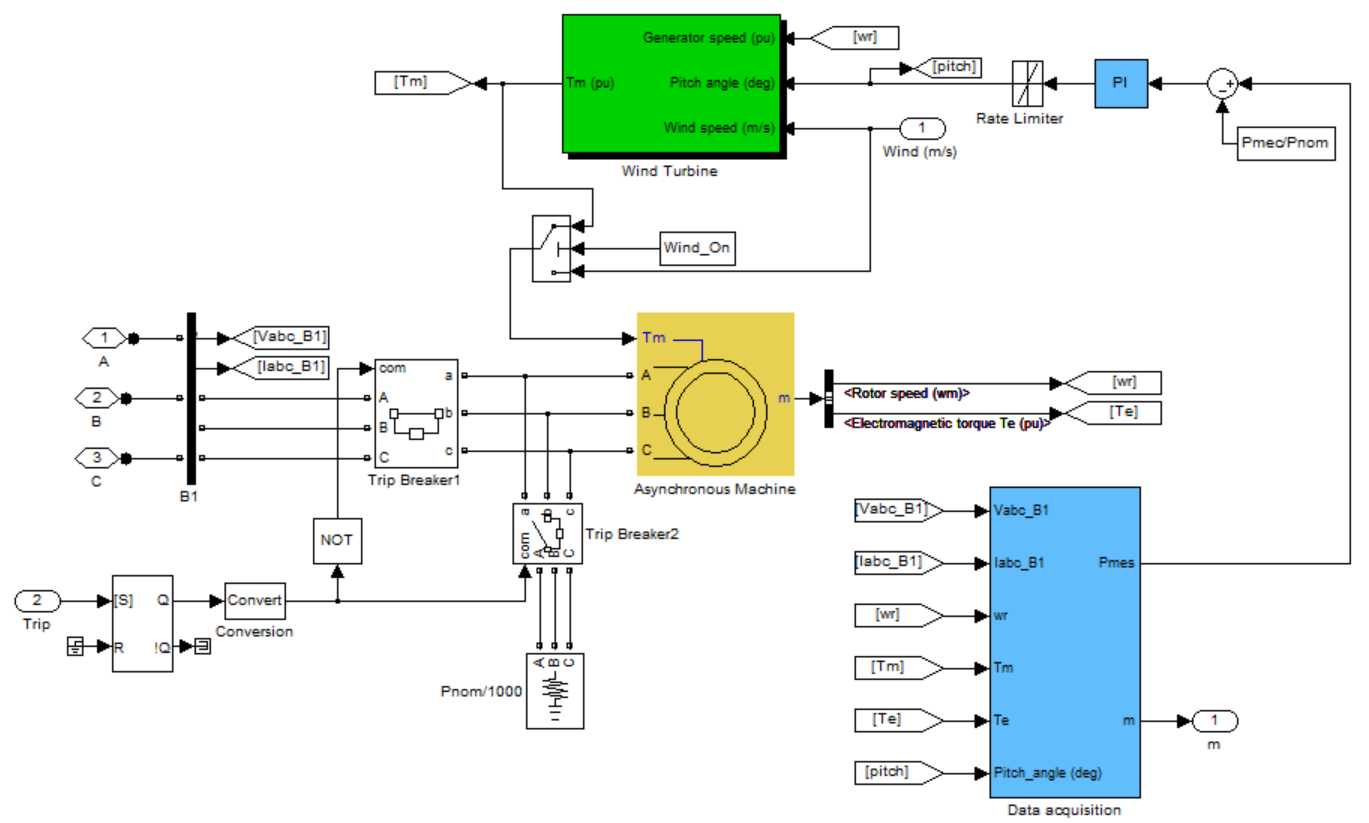

Fig.5. The model of wind turbine and asynchronous machine. 
In the model the wind power, reactive power absorbed by the induction generator is partially compensated by a capacitor bank connected to any wind turbine low voltage bus, the capacity of $400 \mathrm{KVAR}$ for every pair of $1.5 \mathrm{MW}$ turbines. The rest of the required reactive power to maintain voltage at $25 \mathrm{kV}$ bus B25 is close to 1 pu is provided by 3-MVAR STATCOM with $3 \%$ droop setting.

\section{Simulation ReSUlts AND Discussion}

In order to analyse analyze the performance of wind turbine as a part of distributed generation in power distribution system, the overall system is simulated using Matlab Simulink software. The simulation described in this section illustrates the steady-state and dynamic performance of a 9 MW wind power generation system connected to a distribution system. The wind power generation system consists of six $1.5 \mathrm{MW}$ wind turbines connected to a $25 \mathrm{kV}$ distribution system exporting power to a $120 \mathrm{kV}$ grid through a $30 \mathrm{~km} 25 \mathrm{kV}$ feeder. In this simulation, all of the system is observed during $20 \mathrm{~s}$.

Fig. 6 shows the characteristics of the wind turbine with a pitch angle of $0^{\circ}$. This shows that the wind speed will produce a variety of different turbines in the power output per unit of nominal mechanical power. Turbine mechanical power is shown as a function of turbine speed to wind speed ranged between $4 \mathrm{~m} \mathrm{~s}$ to $10 \mathrm{~m} / \mathrm{s}$. In this system it is assumed that the nominal wind speed produces a nominal mechanical power for base 1 p.u. $=3 \mathrm{MW}$ is $9 \mathrm{~m} / \mathrm{s}$. Fig. 7 shows the change of the pitch angle of the wind turbine.

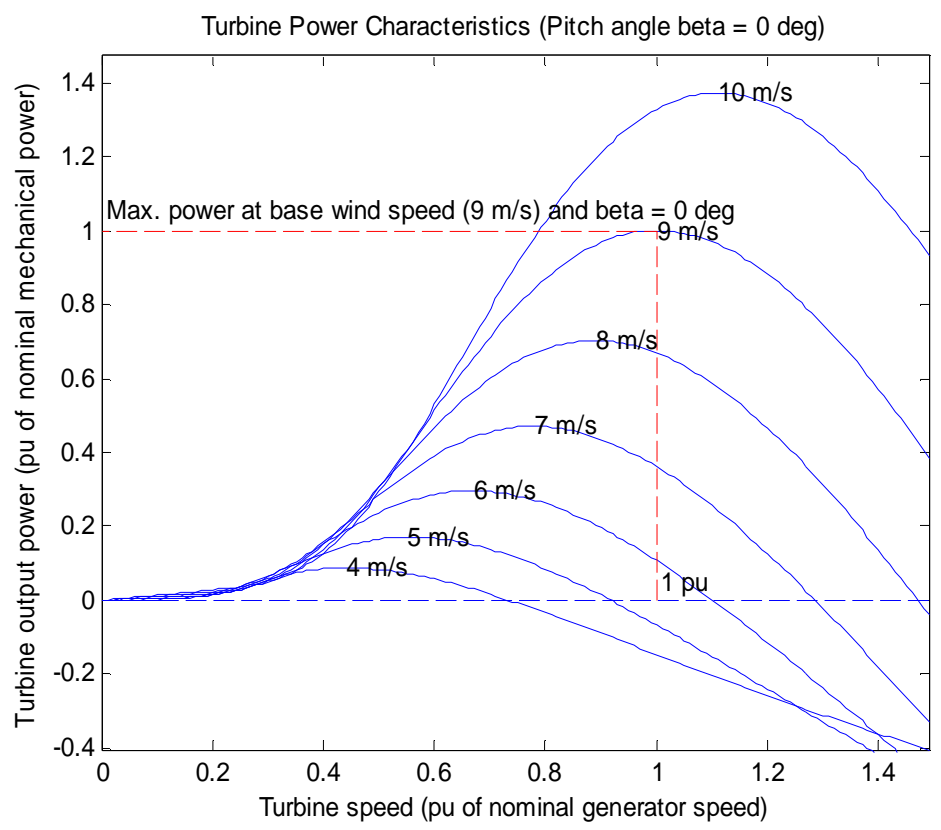

Fig.6. Wind turbine characteristics with pitch angle of $0^{\circ}$. 
International Journal of Computer Science \& Information Technology (IJCSIT) Vol 6, No 3, June 2014

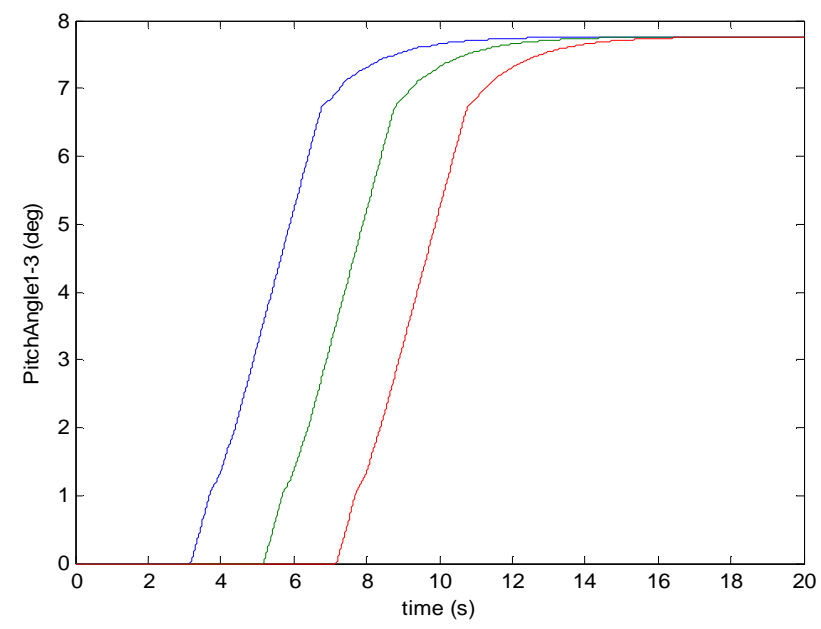

Fig.7. Change of wind turbine pitch angle.

\subsection{Simulation under Normal Condition}

In this part, we have simulated power distribution system including wind turbine as distributed generation under normal condition. Simulation has started with monitoring both active and reactive powers, generator speed, wind speed and pitch angle for each wind turbine.

Fig. 8 and Fig. 9 show the active and reactive power of wind turbine under normal condition, respectively. That Figures illustrate each of the resulted both active and reactive power of three pairs of wind turbines.

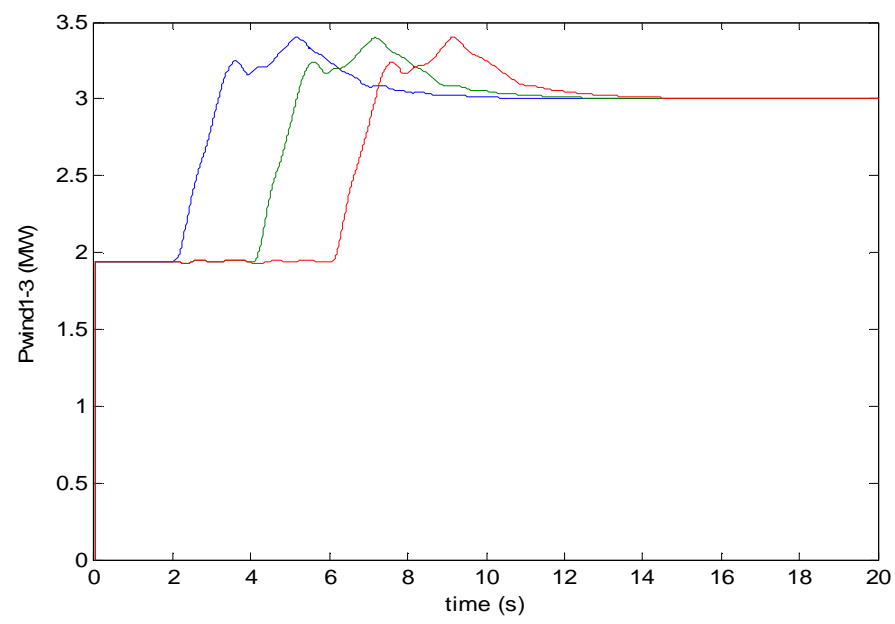

Fig.8. Active power of wind turbineunder normal condition 
International Journal of Computer Science \& Information Technology (IJCSIT) Vol 6, No 3, June 2014

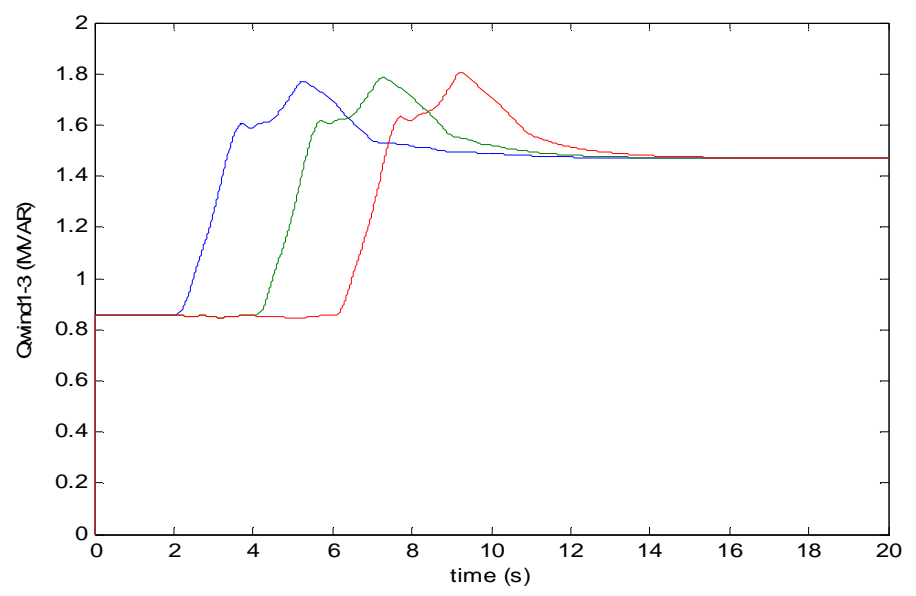

Fig.9. Reactive power of wind turbine under normal condition

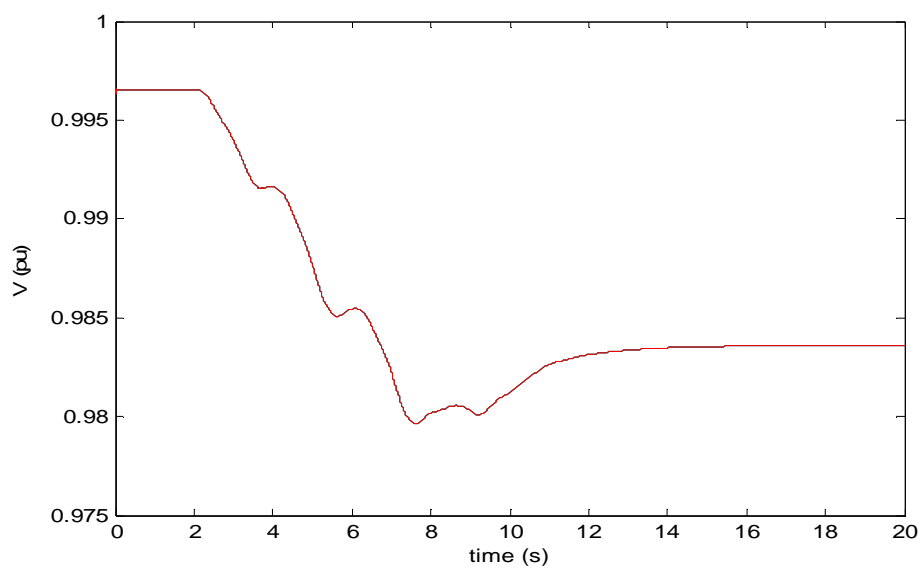

Fig.10. Voltage of bus B25 under normal condition.

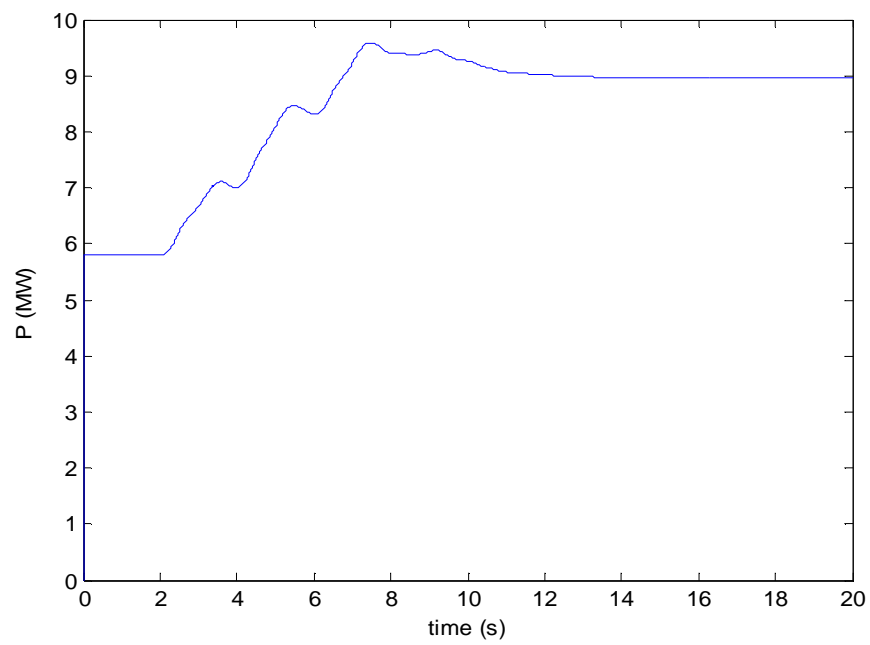

Fig.11. Active power of bus B25 under normal condition 
International Journal of Computer Science \& Information Technology (IJCSIT) Vol 6, No 3, June 2014

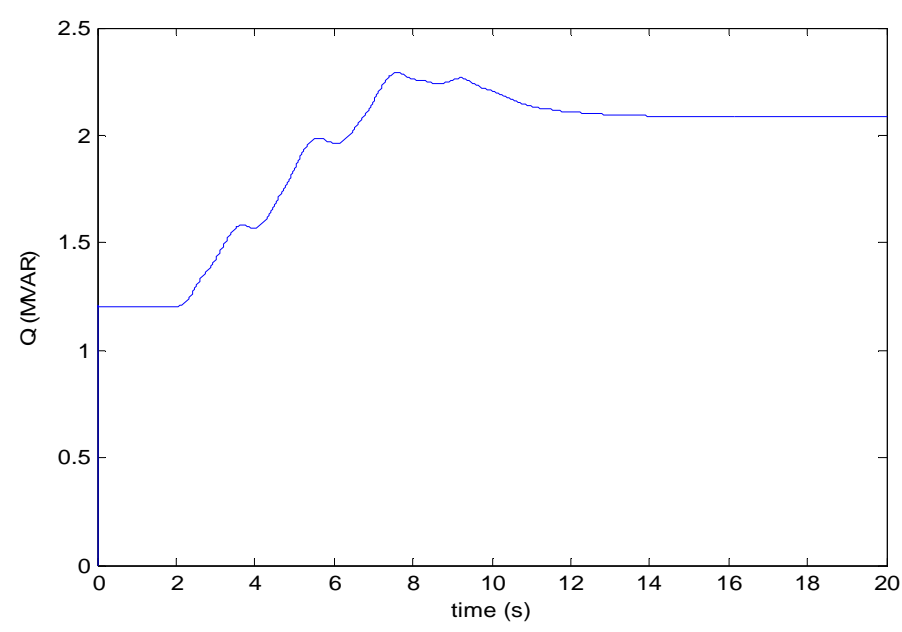

Fig.12. Reactive power of bus B25 under normal condition

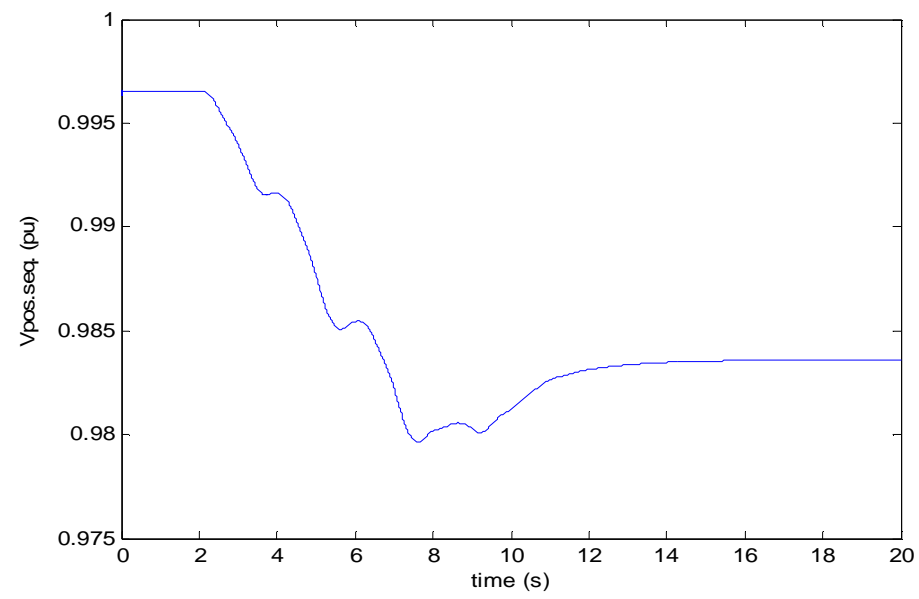

Fig.13. Positive sequence voltage of bus B25 under normal condition

Fig. 10 shows the voltage magnitude of bus B25 (in per unit, p.u.) under normal condition. The voltage has decrease from 0.997 p.u. to 0.980 p.u.in $8 \mathrm{~s}$, and reached the final value of 0.984 p.u. in $12 \mathrm{~s}$.

Fig. 11 shows the active power of bus B25 under normal condition, while Fig. 12 shows the reactive power of bus B25 under the same condition. Both active and reactive power of bus B25 have increased in $8 \mathrm{~s}$, from 5.8 to $9.5 \mathrm{MW}$ and from 1.2 to $2.3 \mathrm{MVAR}$, respectively.

In order to investigate the voltage profile in bus B25 which is connected to wind turbines under normal condition, Fig. 13 and Fig. 14 show the positive sequence voltage and current of bus B25, respectively. From Fig. 13, the positive sequence voltage has decrease from 0.997 p.u. to 0.980 p.u. in $8 \mathrm{~s}$, and reached the final value of 0.984 p.u. in $12 \mathrm{~s}$. While Fig. 14 shows that the positive sequence current has increase from 0.59 p.u. to 1.0 p.u. in $8 \mathrm{~s}$, and reached the final value of 0.984 p.u. in 12 s. 


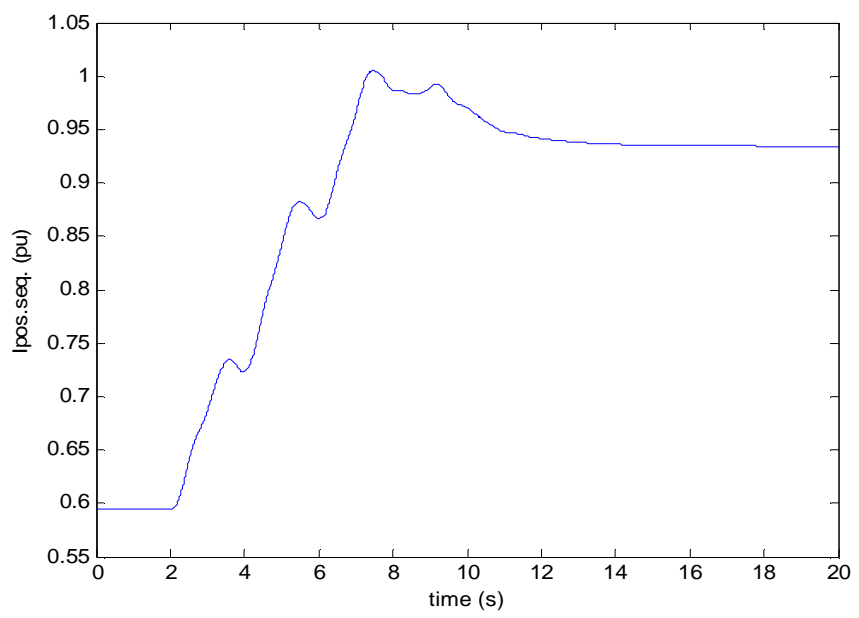

Fig. 14. Positive sequence current of bus B25 under normal condition.

\subsection{Simulation under Fault Condition}

In this session, we have simulated power distribution system including wind turbines as distributed generation under fault condition. At the time $t=15 \mathrm{~s}$, three-phase fault is applied to the wind turbine 2 terminals, causing the wind turbine to trip experience at $t=15.11 \mathrm{~s}$. Once the turbine 2 has tripped, turbine 1 and 3 continued to produce 3 MW each turbine.

Fig. 15 and Fig. 16 show the active and reactive power of wind turbine under fault condition, respectively. The Figures illustrate each of the resulted active and reactive power of three pairs of wind turbines. In Fig. 15, for each pair of active power generating turbines began to rise in tandem with increasing wind speeds to achieve the assessed value of $3 \mathrm{MW}$ in about $8 \mathrm{~s}$. During this period the wind turbine speed has increased from 1.0028 p.u. to 1.0047 p.u. At first turbine blade pitch angle is zero degrees. When the output power exceeds the value of $3 \mathrm{MW}$, the pitch angle is increased from $0^{\circ}$ to $8^{\circ}$ (Fig. 7) to make the output power back to its nominal value.

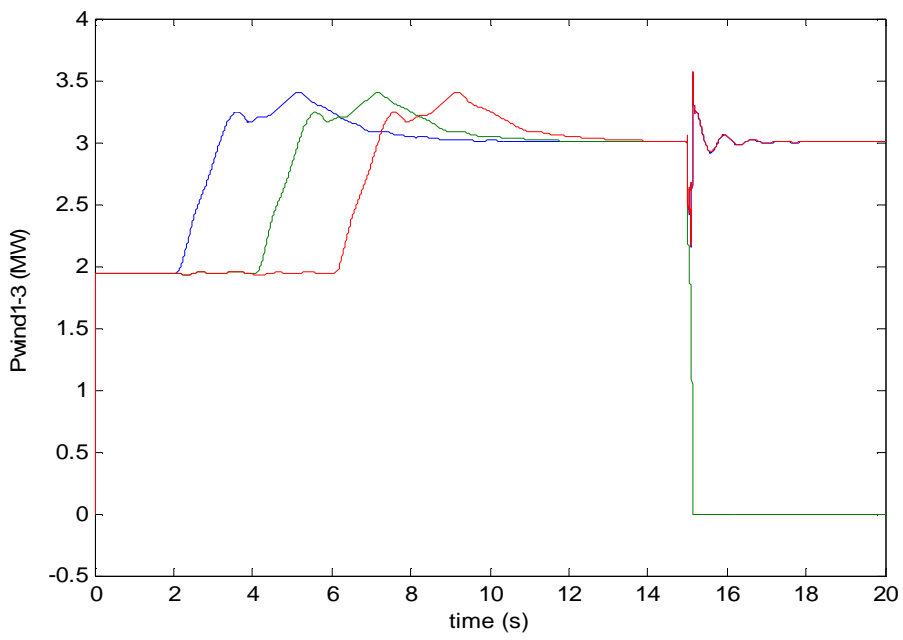

Fig.15. Active power of wind turbine under fault condition 
International Journal of Computer Science \& Information Technology (IJCSIT) Vol 6, No 3, June 2014

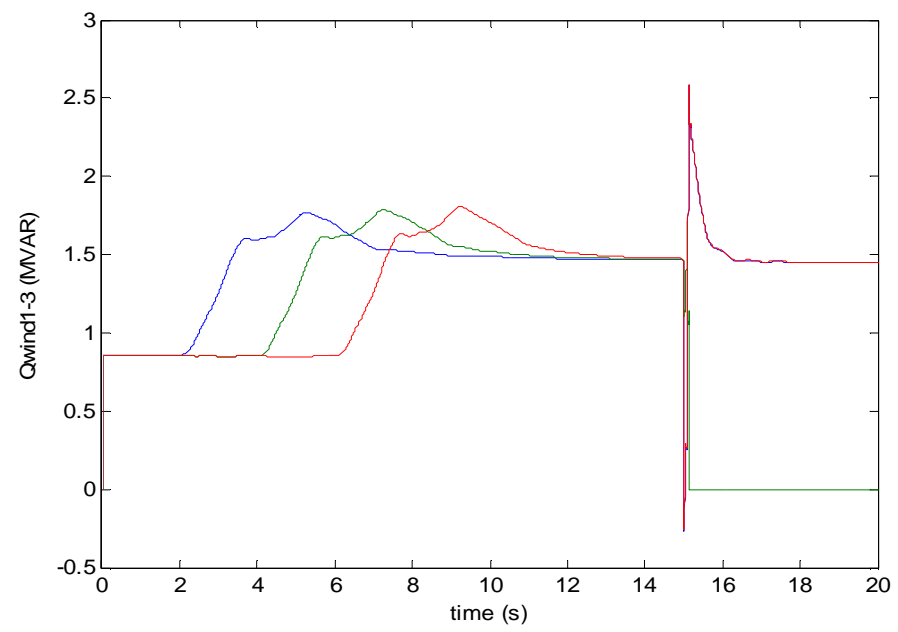

Fig.16. Reactive power of wind turbine under fault condition

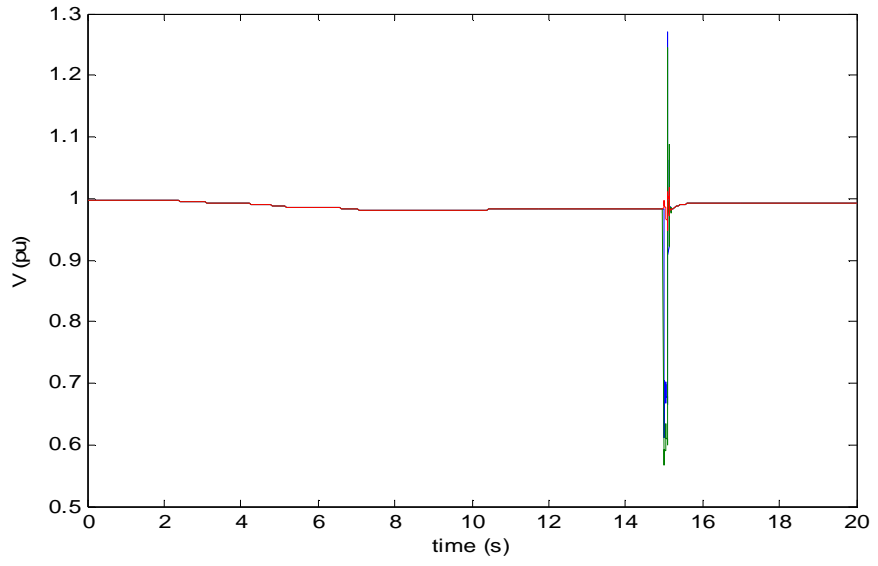

Fig.17. Bus voltage under fault condition

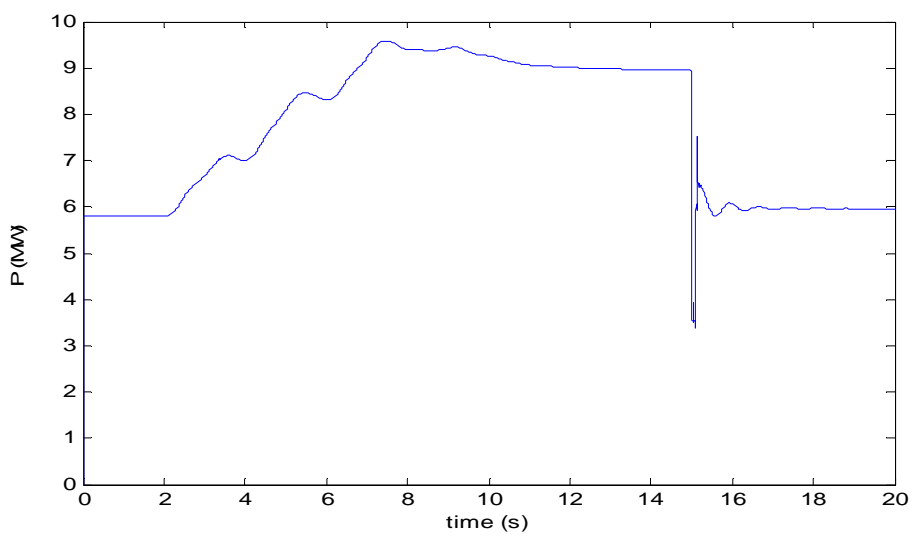

Fig.18. Active power of bus B25 under fault condition 
Fig. 17 shows the bus voltage under fault condition, while Fig. 18 and Fig. 19 show the active and reactive power of bus B25 under fault condition, respectively. From Fig. 17, Fig.18, and Fig.19 can be observed that the absorbed reactive power increases as the generated active power increases. In case of nominal power, each pair of wind turbines will absorb reactive power absorbed by 1.47 MVAR. For turbine operation with $9 \mathrm{~m} / \mathrm{s}$ wind speed, the total power exported measured at bus B25 was $9 \mathrm{MW}$ and voltage can be maintained at a level of 0.984 p.u. by generating reactive power for 1.62 MVAR.

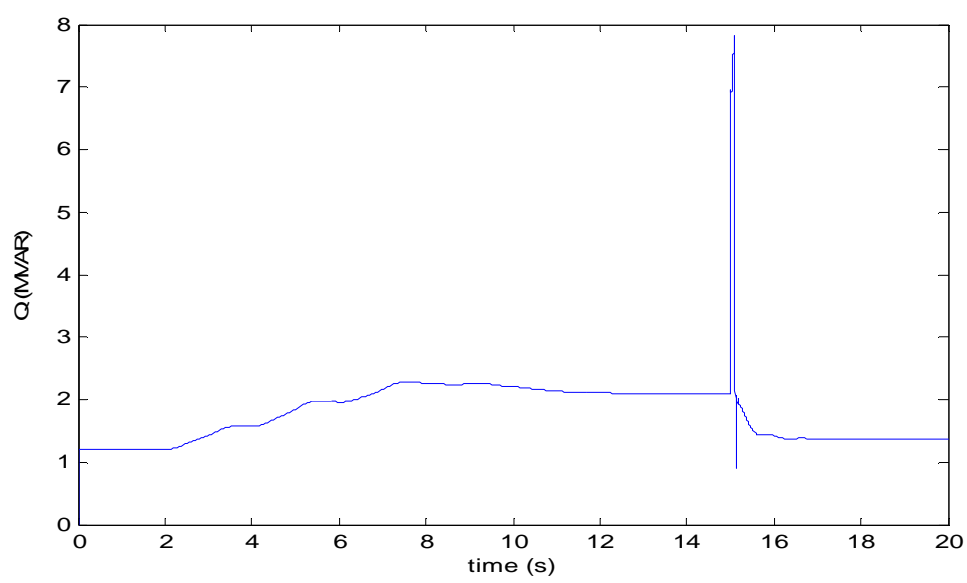

Fig.19. Reactive power of bus B25 under fault condition

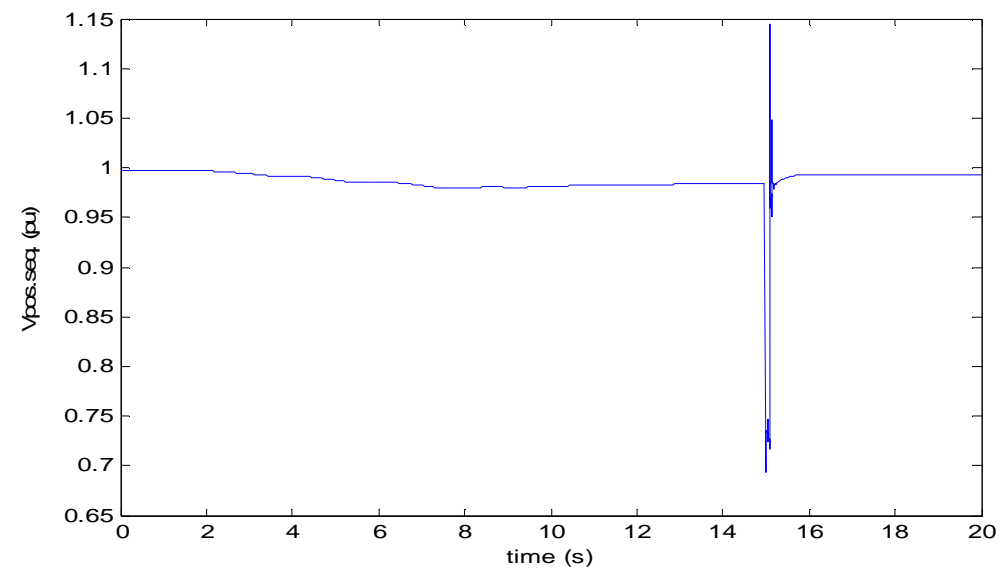

Fig.20. Positive sequence voltage of bus B25 under fault condition 


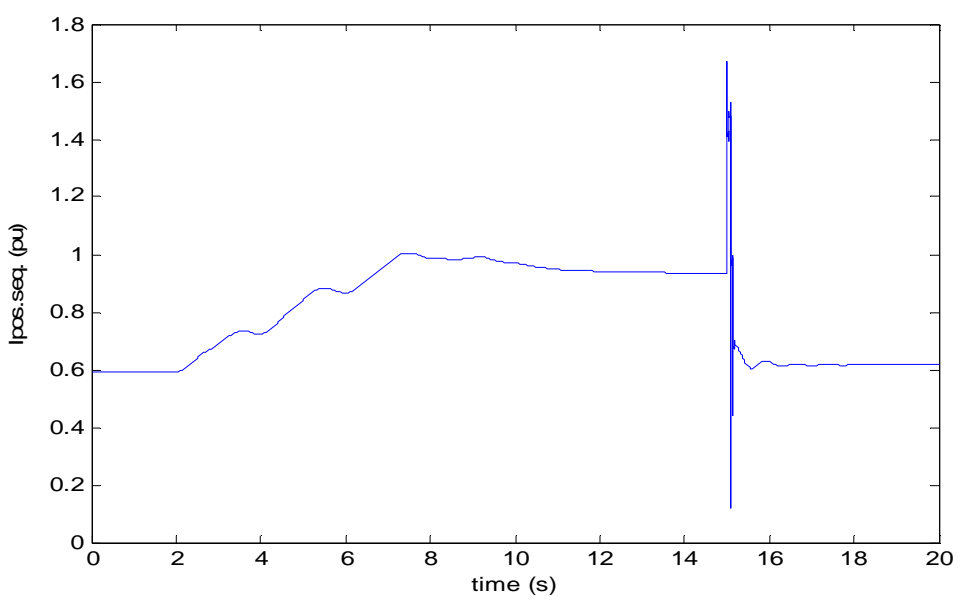

Fig.21. Positive sequence current of bus B25 under fault condition

In order to analyze the voltage profile at bus B25 is connected to the wind power under fault conditions, Fig. 20 and Fig. 21 shows the positive sequence voltage and current bus B25, respectively. From Fig. 20, the positive sequence voltage level has dropped from 0.997 p.u. to 0.980 p.u. within $8 \mathrm{~s}$, and achieve a final value of 0.984 p.u. within $12 \mathrm{~s}$. While Fig. 21 shows that the positive sequence voltage current has an increase of the level of 0.59 p.u. to 1.0 p.u. within 8 $\mathrm{s}$, and reaches the final value of the level of 0.984 p.u. within $10 \mathrm{~s}$. Further investigation is at $\mathrm{t}=$ $15 \mathrm{~s}$, while the three-phase fault has occurred on the low voltage terminal voltage of $575 \mathrm{~V}$ Wind Turbine 2. Results in both voltage and current are the transient oscillations in magnitude. Furthermore, the error can be cleared using the protection system so that the power system has been continuously operating normally.

\section{Conclusions}

This paper presents a performance analysis of wind power as a distributed generation unit. Wind power plant in this study is driven by an induction machine. Wind power that is distributed generation is capable of supplying power to ac power distribution network. Wind power generation system is modeled and simulated using Matlab Simulink software such that it can be suitable for modeling some kind of induction generator configurations. To analyze more deeply the performance of the wind turbine system, both normal and fault conditions scenarios have been applied. Simulation results prove the excellent performance of the wind power unit under normal and fault conditions in the power distribution system.

\section{ACKNOWLEDGEMENTS}

The authors gratefully acknowledge the contributions of the Directorate General of Higher Education (DIKTI), Ministry of Education and Culture, Republic of Indonesia, for funding in this research.

\section{REFERENCES}

[1] L.L. Lai and T.F. Chan, "Distributed Generation, Induction and Permanent Magnet Generators", John Willey and Sons, West Sussex, 2007.

[2] R. Syahputra, I. Robandi, and M. Ashari, "Reconfiguration of Distribution Network with DG Using Fuzzy Multi-objective Method", International Conference on Innovation, Management and Technology Research (ICIMTR), May 21-22, 2012, Melacca, Malaysia. 
[3] D. Kusdiana, "Real conditions in Indonesia Energy Needs and Alternative Sources of Renewable Energy", Presented at the Seminar of Renewable Energy, Directorate General of Electricity and Energy Utilization, Department of Energy and Mineral Resources, 3 Dec. 2008, Bogor, Indonesia.

[4] A. Tapia, G. Tapia, J. X. Ostolaza, and J. R. Saenz, "Modeling and control of a wind turbine driven doubly fed induction generator", IEEE Transactions on Energy Conversion, Vol.18, pp. 194-204, 2003.

[5] R. Syahputra, "Fuzzy Multi-objective Approach for the Improvement of Distribution Network Efficiency by Considering DG', International Journal of Computer Science \& Information Technology (IJCSIT) Vol 4, No 2, April 2012.

[6] Y. Lei, A.Mullane, G.Lightbody, and R.Yacamini, "Modeling of the Wind Turbine With a Doubly Fed Induction Generator for Grid Integration Studies”,IEEE Transactions on Energy Conversion, Vol. 21(1), pp.257-264, 2006.

[7] H.Li and Z.Chen, "Overview of generator topologies for wind turbines",IET Proc. Renewable Power Generation, vol. 2, no. 2, pp. 123-138, Jun.2008.

[8] L. Mihet-Popa and F. Blaabrierg, "Wind Turbine Generator Modeling and Simulation Where Rotational Speed is the Controlled Variable", IEEE Transactions on Industry Applications, Vol. 40, No.1, Jan./Feb. 2004.

[9] S. Kim and E. Kim, "PSCAD/EMTDC-based modeling and analysis of a gearless variable speed wind turbine”, IEEE Trans Energy Conversion, Vol. 22, No. 2, pp. 421-430, 2007.

[10] B.H.Chowary and S. Chellapilla, "Doubly-fed induction generator for variable speed wind power generation” Transactions on Electric Power System Research, Vol.76,pp. 786-800, Jan . 2006.

[11] M.A. Poller, "Doubly-Fed Induction Machine Models for Stability Assessment of Wind Farms", Power Tech Conference Proceedings of 2003 IEEE Bologna, Vol.3, 6 pp. 23-26 June 2003.

[12] B.C. Babu and K.B. Mohanty, "Doubly-Fed Induction Generator for Variable Speed Wind Energy Conversion Systems - Modeling \& Simulation", International Journal of Computer and Electrical Engineering, Vol. 2, No. 1, pp. 1793-8163, February, 2010.

[13] S. Müller,M. Deicke, and R. W.De Doncker, "Doubly-fed induction generator system for wind turbines", IEEE Industry Applications Magazine, May/June 2002.

[14] J.G. Slootweg, S. W. H. Haan, H. Polinder, and W.L. Kling. "General Model for Representing Variable Speed Wind Turbines in Power System Dynamics Simulations”. IEEE Trans. on Power Systems, Vol. 18, No. 1, February, 2003.

[15] T. T. Chuong, "Voltage Stability Investigation of Grid Connected Wind Farm", World Academy of Science, Engineering and Technology, Vol. 42, pp. 532-536, 2008.

\section{Authors}

Ramadoni Syahputra was born in Galang-Deli Serdang, North Sumatera, Indonesia, on October 10, 1974. He received M.Eng. degree from Department of Electrical Engineering, Universitas Gadjah Mada, Yogyakarta, Indonesia in 2002. $\mathrm{He}$ is currently a Ph.D. candidate at the Electrical Engineering,Institut Teknologi Sepuluh Nopember, Surabaya, Indonesia. He is a Lecturer in the Department of Electrical Engineering, Faculty of Engineering, Universitas Muhammadiyah Yogyakarta, Indonesia. His research interests are in power system operation, computational of power system, artificial intelligence in power system, power system control, power quality, distributed generation, and renewable energy.

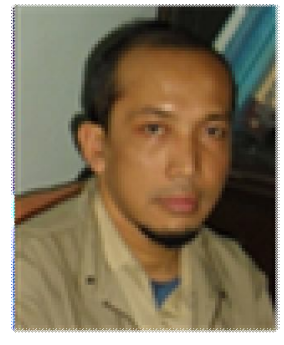

Imam Robandi was born in Kebumen, Central Java, Indonesia on August 17, 1963. $\mathrm{He}$ received the Ph.D. degree form Tottori University, Japan. He is currently a Professor in the Department of Electrical Engineering, Faculty of Industrial Technology, Institut Teknologi Sepuluh Nopember, Surabaya, Indonesia. His research interests are in power system operation, power electronics, power system control, artificial intelligence in power system control, power quality, distributed generation, micro grid simulation, power system automation, and renewable energy.

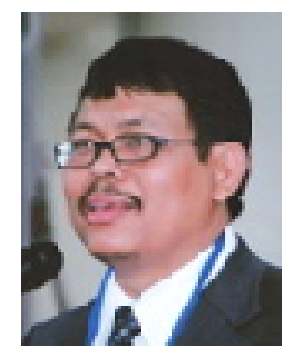


International Journal of Computer Science \& Information Technology (IJCSIT) Vol 6, No 3, June 2014

Mochamad Ashari was born in Sidoarjo, East Java, Indonesia on October 12, 1965. He received the M.Eng. and Ph.D. degrees form Curtin University, Australia, in 1997 and 2001, respectively. He is currently a Professor in the Department of Electrical Engineering, Faculty of Industrial Technology, Institut Teknologi Sepuluh Nopember, Surabaya, Indonesia. His research interests are in power system operation, power electronics, artificial intelligence in power system, power system control, optimization of power system, distributed generation, micro grid simulation, power quality, and renewable energy.

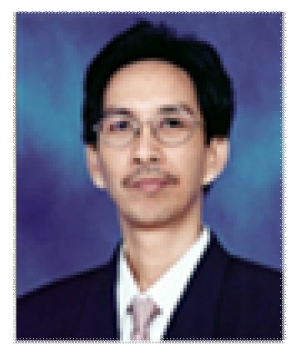

\section{APPENDIX}

Table A.1. Generator Data (Asynchronous Machine)

\begin{tabular}{|l|l|l|l|}
\hline Variable & Value & Variable & Value \\
\hline Nominal power & $2 * 1.5 \mathrm{e} 6 / 0.9 \mathrm{VA}$ & Rotor Resistance $(\mathrm{Rr}$ ') & 0.004377 p.u. \\
\hline Voltage (L-L) & $575 \mathrm{Vrms}$ & Rotor Inductance $\left(\mathrm{L} 1 r^{\prime}\right)$ & 0.1791 p.u. \\
\hline Frequency & $60 \mathrm{~Hz}$ & Inertia constant $(\mathrm{H})$ & $5.04 \mathrm{~s}$ \\
\hline Stator Resistance (Rs) & 0.004843 p.u. & Friction factor & 0.01 p.u. \\
\hline Stator Inductance (L1s) & 0.1248 p.u. & Pairs of poles & $3 \mathrm{p}$ \\
\hline Magnetizing inductance (Lm) & 6.77 p.u. & - & - \\
\hline
\end{tabular}

Table A.2. Wind Turbine Data

\begin{tabular}{|l|l|l|l|}
\hline Variable & Value & Variable & Value \\
\hline $\begin{array}{l}\text { Nominal wind turbine mechanical } \\
\text { output power }\end{array}$ & $\begin{array}{l}2 * 1.5 \mathrm{e} 6 \\
\mathrm{~W}\end{array}$ & Pitch angle controller gain $(\mathrm{Kp})$ & 5 \\
\hline Base wind speed & $9 \mathrm{~m} / \mathrm{s}$ & Pitch angle controller gain $(\mathrm{Ki})$ & 25 \\
\hline Maximum power at base wind speed & 1 p.u. & Maximum pitch angle & $45 \mathrm{deg}$ \\
\hline Base rotational speed & 1 p.u. & $\begin{array}{l}\text { Maximum rate of change of } \\
\text { pitch angle }\end{array}$ & $2 \mathrm{deg} / \mathrm{s}$ \\
\hline
\end{tabular}

Table A.3. Three Phase Transformer 25 kV/ 575 V, 4 MVA

\begin{tabular}{|l|l|l|l|}
\hline Variable & Value & Variable & Value \\
\hline $\begin{array}{l}\text { Winding 1 connection (ABC } \\
\text { terminals) }\end{array}$ & Yg & $\begin{array}{l}\text { Winding 1 parameter } \\
\text { (V1) }\end{array}$ & 25e3 Vrms \\
\hline $\begin{array}{l}\text { Winding 2 connection (abc } \\
\text { terminals) }\end{array}$ & Yn & $\begin{array}{l}\text { Winding 1 parameter } \\
(\mathrm{R} 1)\end{array}$ & $0.025 / 30$ p.u. \\
\hline Nominal power $(\mathrm{Pn})$ & 4e6 VA & $\begin{array}{l}\text { Winding 1 parameter } \\
(\mathrm{L} 1)\end{array}$ & 0.025 p.u. \\
\hline Frequency & $60 \mathrm{~Hz}$ & $\begin{array}{l}\text { Winding 2 parameter } \\
(\text { V2) }\end{array}$ & 575 Vrms \\
\hline Magnetization resistance $(\mathrm{Rm})$ & 500 & $\begin{array}{l}\text { Winding 2 parameter } \\
(\mathrm{R} 2)\end{array}$ & $0.025 / 30$ p.u. \\
\hline Magnetization inductance $(\mathrm{Lm})$ & inf & $\begin{array}{l}\text { Winding 2 parameter } \\
(\mathrm{L} 2)\end{array}$ & 0.025 p.u. \\
\hline
\end{tabular}


International Journal of Computer Science \& Information Technology (IJCSIT) Vol 6, No 3, June 2014

Table A.4. Three Phase PI Section $1 \mathrm{~km}$ Line

\begin{tabular}{|l|l|l|l|}
\hline Variable & Value & Variable & Value \\
\hline Frequency used for R L C & $60 \mathrm{~Hz}$ & $\begin{array}{l}\text { Positive-sequence inductances } \\
(\mathrm{L} 1)\end{array}$ & $1.05 \mathrm{e}-3 \mathrm{H} / \mathrm{km}$ \\
\hline $\begin{array}{l}\text { Positive-sequence resistances } \\
(\mathrm{R} 1)\end{array}$ & $0.1153 \mathrm{Ohms} / \mathrm{km}$ & Zero-sequence inductances (L0) & $3.32 \mathrm{e}-3 \mathrm{H} / \mathrm{km}$ \\
\hline $\begin{array}{l}\text { Zero-sequence resistances } \\
(\mathrm{R} 0)\end{array}$ & $\begin{array}{l}0.413 \\
\text { Ohms/km }\end{array}$ & $\begin{array}{l}\text { Positive-sequence capacitances } \\
(\mathrm{C} 1)\end{array}$ & $11.33 \mathrm{e}-009 \mathrm{~F} / \mathrm{km}$ \\
\hline Line section length & $1 \mathrm{~km}$ & Zero-sequence capacitances $(\mathrm{C} 0)$ & $\begin{array}{l}5.01 \mathrm{e}-009 \\
\mathrm{~F} / \mathrm{km}\end{array}$ \\
\hline
\end{tabular}

Table A.5. Three Phase Series RLC Load

\begin{tabular}{|l|l|l|l|}
\hline Variable & Value & Variable & Value \\
\hline Nominal Frequency & $60 \mathrm{~Hz}$ & $\begin{array}{l}\text { Nominal phase-to-phase voltage } \\
(\text { Vn) }\end{array}$ & $575 \mathrm{Vrms}$ \\
\hline Configuration & Delta & Capacitive reactive power (Qc) & $400 \mathrm{e} 3 \mathrm{VAR}$ \\
\hline
\end{tabular}

Table A.6. Bus B25 (25kV)

\begin{tabular}{|l|l|l|l|}
\hline Variable & Value & Variable & Value \\
\hline Nominal Frequency & $60 \mathrm{~Hz}$ & Nominal voltage used for p.u. & $25 \mathrm{e} 3 \mathrm{Vrms}$ \\
\hline Base power (3 phase) & $10 \mathrm{e} 6 \mathrm{VA}$ & - & - \\
\hline
\end{tabular}

Table A.7. Three Phase PI Section 25 km Line

\begin{tabular}{|l|l|l|l|}
\hline Variable & Value & Variable & Value \\
\hline Frequency used for R L C & $60 \mathrm{~Hz}$ & $\begin{array}{l}\text { Positive-sequence inductances } \\
\text { (L1) }\end{array}$ & $1.05 \mathrm{e}-3 \mathrm{H} / \mathrm{km}$ \\
\hline $\begin{array}{l}\text { Positive-sequence resistances } \\
(\mathrm{R} 1)\end{array}$ & $\begin{array}{l}0.1153 \\
\text { Ohms/km }\end{array}$ & $\begin{array}{l}\text { Zero-sequence inductances } \\
\text { (L0) }\end{array}$ & $3.32 \mathrm{e}-3 \mathrm{H} / \mathrm{km}$ \\
\hline $\begin{array}{l}\text { Zero-sequence resistances } \\
(\mathrm{R} 0)\end{array}$ & $\begin{array}{l}0.413 \\
\text { Ohms/km }\end{array}$ & $\begin{array}{l}\text { Positive-sequence capacitances } \\
\text { (C1) }\end{array}$ & $\begin{array}{l}11.33 \mathrm{e}-009 \\
\text { F/km }\end{array}$ \\
\hline Line section length & $25 \mathrm{~km}$ & $\begin{array}{l}\text { Zero-sequence capacitances } \\
\text { (C0) }\end{array}$ & $5.01 \mathrm{e}-009 \mathrm{~F} / \mathrm{km}$ \\
\hline
\end{tabular}

Table A.8. Three Phase Transformer 120 kV/25 kV, 47 MVA

\begin{tabular}{|l|l|l|l|}
\hline Variable & Value & Variable & Value \\
\hline $\begin{array}{l}\text { Winding 1 connection (ABC } \\
\text { terminals) }\end{array}$ & Yg & $\begin{array}{l}\text { Winding 1 parameter } \\
(\text { V1) }\end{array}$ & $120 \mathrm{e}$ Vrms \\
\hline $\begin{array}{l}\text { Winding 2 connection (abc } \\
\text { terminals) }\end{array}$ & Delta(D11) & $\begin{array}{l}\text { Winding 1 parameter } \\
(\mathrm{R} 1)\end{array}$ & $0.08 / 30$ p.u. \\
\hline Nominal power $(\mathrm{Pn})$ & $4 \mathrm{e} 6 \mathrm{VA}$ & $\begin{array}{l}\text { Winding 1 parameter } \\
(\mathrm{L} 1)\end{array}$ & 0.08 p.u. \\
\hline Frequency & $60 \mathrm{~Hz}$ & $\begin{array}{l}\text { Winding 2 parameter } \\
(\text { V2) }\end{array}$ & $25 \mathrm{e}$ Vrms \\
\hline Magnetization resistance $(\mathrm{Rm})$ & 500 & $\begin{array}{l}\text { Winding 2 parameter } \\
(\mathrm{R} 2)\end{array}$ & $0.08 / 30 \mathrm{p} . \mathrm{u}$. \\
\hline Magnetization inductance $(\mathrm{Lm})$ & 500 & $\begin{array}{l}\text { Winding 2 parameter } \\
(\mathrm{L} 2)\end{array}$ & 0.08 p.u. \\
\hline
\end{tabular}


International Journal of Computer Science \& Information Technology (IJCSIT) Vol 6, No 3, June 2014

Table A.9. Three Phase Mutual Inductance Z1-Z0, 2500 MVA, X0/X1=3

\begin{tabular}{|l|l|l|l|}
\hline Variable & Value & Variable & Value \\
\hline $\begin{array}{l}\text { Positive-sequence resistances } \\
(\mathrm{R} 1)\end{array}$ & $0.1 \mathrm{Ohms}$ & $\begin{array}{l}\text { Positive-seq. inductances } \\
(\mathrm{L} 1)\end{array}$ & $\begin{array}{l}\left.1.0 /\left(2^{*} \mathrm{pi} * 60\right)\right] * 120 \mathrm{e} 3^{\wedge} 2 / 2500 \mathrm{e} \\
\mathrm{H}\end{array}$ \\
\hline $\begin{array}{l}\text { Zero-sequence resistances } \\
(\mathrm{R} 0)\end{array}$ & $0.3 \mathrm{Ohms}$ & $\begin{array}{l}\text { Zero-seq. inductances } \\
(\mathrm{L} 0)\end{array}$ & $\begin{array}{l}3.0 /(2 * \mathrm{pi} * 60)] \\
* 120 \mathrm{e} 3^{\wedge} 2 / 2500 \mathrm{e} 6 \mathrm{H}\end{array}$ \\
\hline
\end{tabular}

Table A.10. Three Phase Programmable Voltage Source 120 kV, 60 Hz

\begin{tabular}{|l|l|l|l|}
\hline Variable & Value & Variable & Value \\
\hline $\begin{array}{l}\text { Positive-sequence voltage } \\
\text { (R1) }\end{array}$ & $120 \mathrm{e} 3 \mathrm{Vrms}$ & Positive-sequence phase & $0 \mathrm{deg}$ \\
\hline
\end{tabular}

